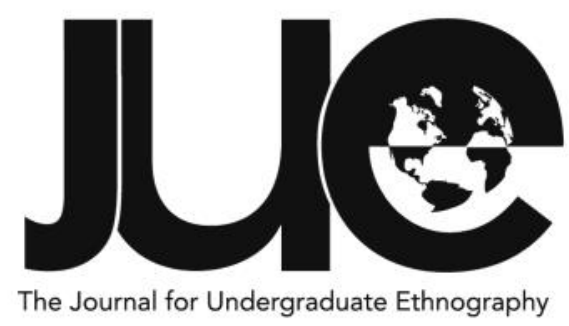

\title{
Mules for Cartels: Survival and Clandestine Migration in the Sonoran Desert
}

\author{
Bill De La Rosa
}

Bowdoin College, delarosa.bill1@gmail.com

\section{ABSTRACT}

Since the early 1990s, United States border strategies have relied on hazardous natural environments to deter clandestine migration. American lawmakers believed that by securing urban entryways and making clandestine migration difficult, migrants would be discouraged from illegally crossing the United States-Mexico border. Instead, however, these policies inhumanely funneled migration flows toward the forbidding Arizona desert. Consequently, for more than two decades, migrants have been enduring dangerous environments while sharing transitory space with human smugglers and, more recently, drug traffickers, who rely on the same paths into the United States. Using a framework of structural violence, this paper explores how migrants navigate clandestine migration in the Sonoran Desert, particularly as they become beholden to drug cartels, which, in exchange for assistance in crossing the border, insist that migrants transport illicit drugs. Drawing on two summers of ethnographic research at a migrant shelter in Nogales, Mexico, I argue that migrants are not only victims but also agents who employ specific forms of capital to survive highly violent situations during this process. This research reveals the intricacies of today's clandestine migration across the Arizona-Sonora border and further illustrates the nuances of structural violence. 
F rancisco was a sight. His eyes were bloodshot and his face weathered like sandpaper. Recently deported from the United States (U.S.) after the Border Patrol found him disoriented and severely dehydrated in the Sonoran Desert, he took off his hat and stared at the floor as he recalled his rugged trek through the fierce summer heat that can reach up to 115 degrees. "Your skin begins to burn, your shoes start to melt; you grow desperate. I stripped naked, rolled in the dirt, and began to shout as loud as I could, but no one heard me," he related. Out of desperation his sanity wavered: "I then took out a lighter and lit a mesquite tree on fire." Igniting a tree on fire alerted authorities nearby, which saved his life. Francisco was one of thousands of migrants fleeing from personal, political, and economic insecurities in Mexico and Central America, and one of several migrants I interviewed at a migrant shelter in Nogales, Mexico, during the summers of 2014 and 2015.

For over two decades, people like Francisco have risked their lives crossing the Sonoran Desert to clandestinely enter the U.S. In the early 1990's, U.S. border controls changed to emphasize preventative measures to discourage unlawful entries (Cornelius 2001; Cornelius 2005). The change was based on a 1993 study commissioned by the U.S. and conducted by Sandia National Laboratories, a national security research institution, which concluded that it was more cost effective for the U.S. Border Patrol to deter migrants at the border rather than trying to apprehend them once they were already in the U.S. (Cornelius 2001, 662). Subsequently, a series of strategies incorporating preventative logics were implemented along the U.S.-Mexico border. The first strategy was Operation Hold-the-Line in El Paso, Texas in 1993, followed by Operation

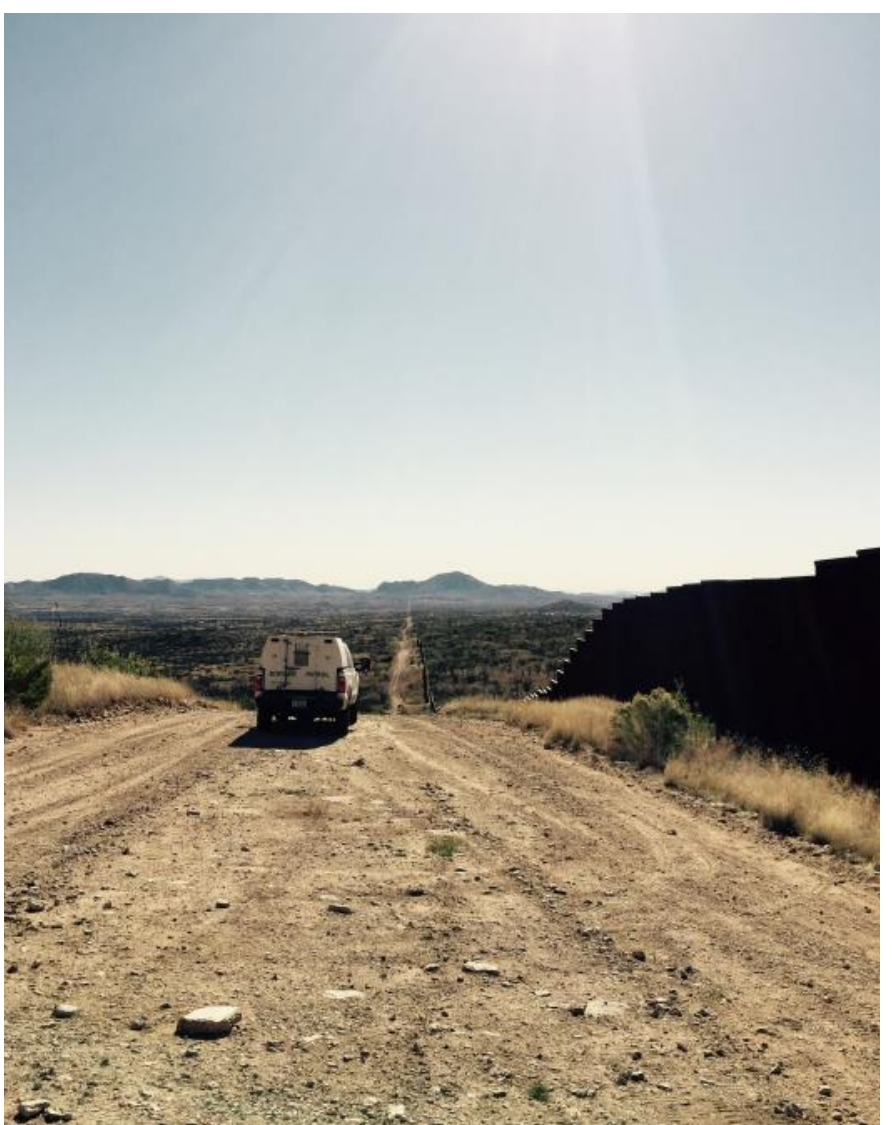

Figure 1: a Border Patrol vehicle patrolling the U.S.-Mexico border near the outskirts of Sasabe, Arizona. Photo: Bill De La Rosa, 2016.

Gatekeeper in Southern California and Operation Safeguard in Southern Arizona in 1994. All of these strategies augmented the Border Patrol's presence on major border towns through the deployment of helicopters, vehicles, video remote surveillance systems, and thousands of agents. Then, in July 1994, the U.S. Immigration Naturalization Services (INS) mandated the national implementation of Prevention Through Deterrence (PTD), which permanently prioritized prevention efforts, heavily relying on the Arizona desert as the solution for stopping clandestine migration. Border Patrol vehicles regularly patrol the U.S.Mexico border near the outskirts of Sasabe, Arizona to deter border crossings (see Figure 1). In the Land of Open Graves, De León (2015) thoroughly describes the systematic construction of PTD, its cynical purpose, and its deadly consequences.

The shift in enforcement efforts catastrophically influenced migration patterns. According to the United States General Accounting Office (1997), the policy has two key 
objectives: "(1) close off the routes most frequently used by smugglers and illegal aliens (generally through urban areas) and (2) shift traffic through the ports of entry or over areas that were more remote and difficult to cross illegally, where INS had the tactical advantage" (64). In other words, the logic underlying PTD concluded that people would be discouraged from crossing the desert if the risks became drastic (Inda 2006; RubioGoldsmith et al. 2006; Andreas 2009; De León 2012; De León 2015). However, instead of deterring clandestine migration, the strategy played a fundamental role in channeling migrants through treacherous areas of southern Arizona. Consequently, thousands of men, women, and children have perished as a result of this social process. As of January 2018, more than 3,000 human remains have been found in the Sonoran Desert; according to estimates from the American Civil Liberties Union, the total death count exceeds 5,000 people (Jimenez 2009).

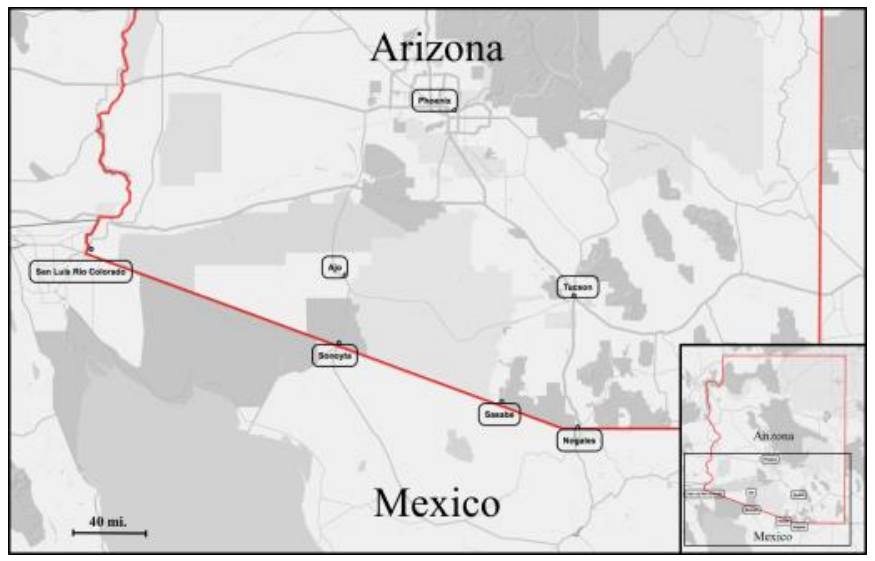

Figure 2: Map of southern Arizona showing the towns mentioned in this article. Source: Bill De La Rosa, 2017.

The interviews and stories I gathered during my fieldwork inform the purpose of this article, which is to examine how migrants navigate violent situations as they risk their lives crossing the Sonoran Desert. Because of the violent nature of clandestine migration, migrants have historically relied on the human-trafficking industry for assistance. Today, however, clandestine border crossings in southern Arizona (see map in Figure 2) are evolving due to the presence of drug cartels along the Arizona-Sonora border. As my ethnographic material reveals, migrants are becoming beholden to drug cartels, which, in exchange for assistance in crossing the border, insist that migrants also transport illicit drugs. I argue that during this process, migrants are victims and, more importantly, agents employing specific forms of capital in order to survive under violent situations. Their experiences reveal the evolving complexities of clandestine migration and contribute to our understanding of structural violence, in addition to the human consequences of heightened U.S. border enforcement policies.

\section{Structural Violence and Social Capital in Clandestine Migration}

Clandestine migration across the U.S.-Mexico border is a multifaceted, well-structured process that encompasses multiple social actors (Singer and Massey 1998). To understand this process today and the precarious decisions migrants make, my literature review draws on the notions of structural violence and social capital, particularly as they relate to the migratory process across the Arizona-Sonora border, and covers recent scholarship on clandestine border crossings.

Galtung (1969) first defined structural violence as a form of violence that is discreet, indirect, and unattributable to an individual actor. According to Galtung, structural violence is "built into the structure and shows up as unequal power and consequently as unequal life changes" (1969, 171). For him, social structures play an integral role in creating violence through enforced marginalization and systemic inequalities. On the other hand, "personal violence represents change and dynamism," he says, "not only ripples on waves, but waves on otherwise tranquil waters. Structural violence is silent, it does not show-it is essentially static, it is the tranquil waves" (1969, 173).

How, then, may structural violence manifest itself across the Arizona-Sonora border? In the context of clandestine migration, Nevins explains how structural violence "emerges out of a complex web of social relations that involves individual acts, structures and processes, as well as discourse, or expressions 
of communication" $(2005,16)$, which often casts blame upon migrants who find themselves in dangerous situations for engaging in surreptitious activities. For him, the funneling effect of border strategies contributes to people's marginalization and suffering in the Sonoran Desert. In this respect, Nevins declares, "the principal perpetrators of this violence are the state actors who, under the rubric of the law, construct the boundaries and illegalize the unauthorized immigrants, thus making such deaths inevitable" (2005, 17). Simply put, while one migrant death in a desert could be portrayed as an isolated tragedy, when more than 3,000 cadavers have been recovered (see Figure 3), then there are external structures, such as U.S. border policy, that must be examined.

Slack and Whiteford (2011) claim that current conceptions of structural violence often overshadow the individual autonomy people employ while navigating stringent conditions. They propose the term "post-structural violence" to understand and describe the "way people react within the confines of a situation precipitated by structural violence" (Slack and Whiteford 2011, 13). During the migratory process, according to Slack and Whiteford, poststructural violence "requires people to navigate a series of difficult decisions" and "[take] roles that increase their chances of death, while decreasing their vulnerability to structural violence" $(2011,13)$. I agree with this assertion, and would also add that this process is highly nuanced, because as my ethnographic examples illustrate, migrants are carefully calculating the risks and benefits of their situation to avoid death and survive in the Sonoran Desert, even when reluctantly operating as mules for cartels.

\section{9 - 2016 RECORDED MIGRANT DEATHS AND WATER STATIONS}

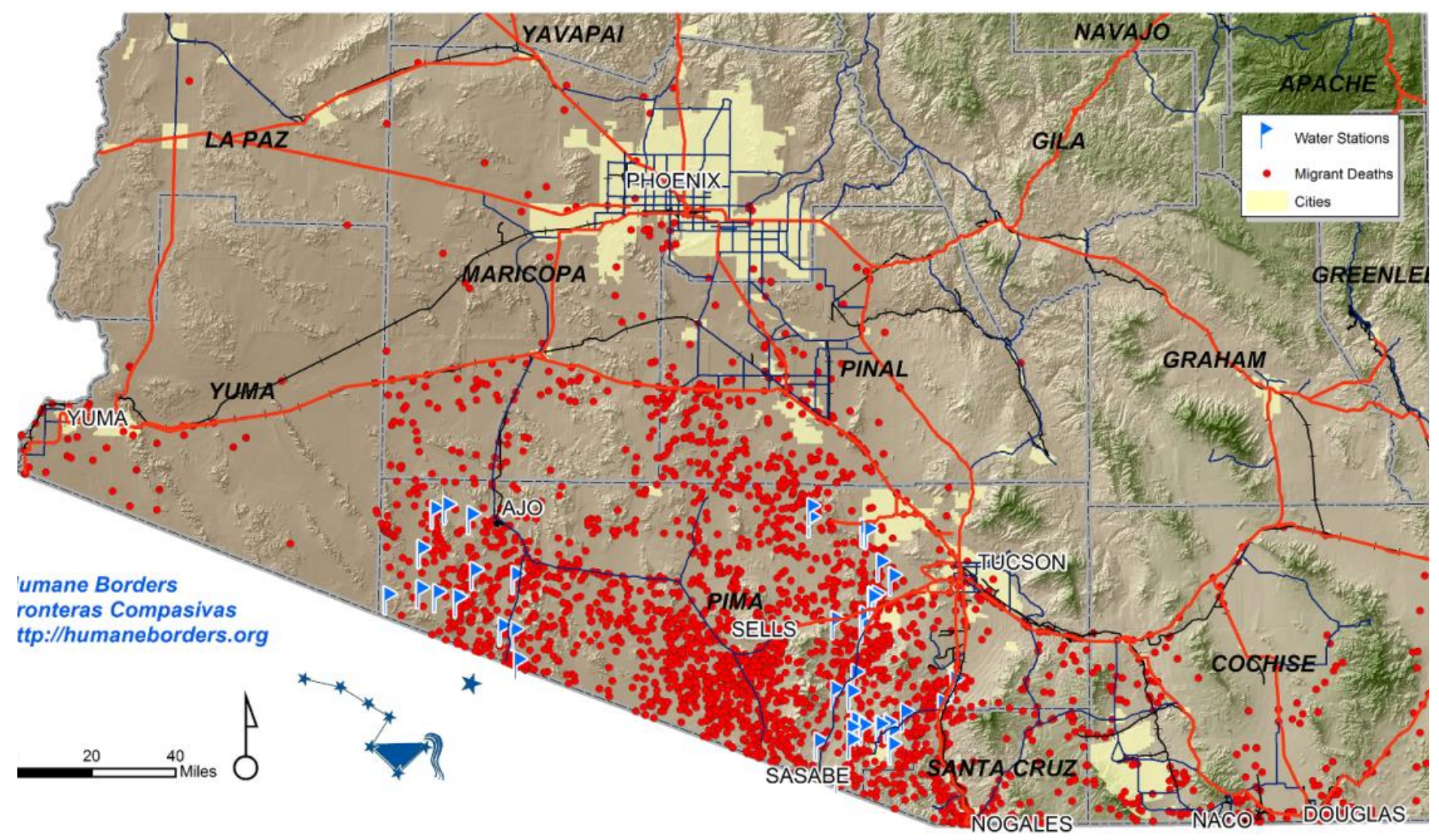

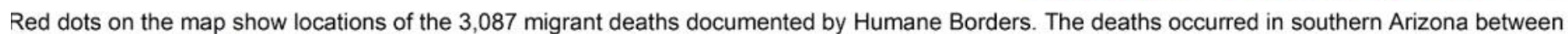

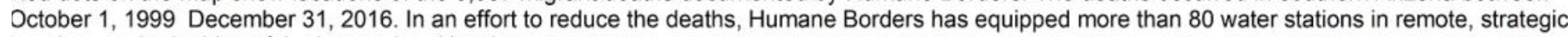
ocations on both sides of the international border.

Figure 3: map of 3,087 migrant deaths in the Sonoran Desert documented by Humane Borders, a nongovernmental organization in Arizona. Source: humaneborders.org, accessed 30 July 2017. 
One way of understanding how migrants fight for survival is to draw on the knowledge that has been produced and shared from previous clandestine border crossings. In Outline of a Theory of Practice, Bourdieu (1977) refers to this production of knowledge as "social capital" - a process which explains how individuals accumulate resources from social relationships. Furthermore, Bourdieu (1977), through the concept of "habitus," explains how people's learned perspectives constitute both past and present perceptions, actions, and dispositions. His notion of habitus, particularly as it relates to the accumulation of social capital from each border crossing, is important for understanding the social process of clandestine migration in the Sonoran Desert.

For instance, Singer and Massey (1998) found that more than two decades ago, migrants tended to rely on family members and coyotes [human smugglers] to cross the border in their first attempt. They coin the term "migration-specific capital" to conceptualize how clandestine migrants, who were once dependent on others, subsequently crossed the border alone, as they accumulated valuable knowledge from each crossing (for example, what items to bring, the length of time it would take to cross, etc.) (Singer and Massey 1998, 569). Consequently, generations of clandestine migration from Mexico to the U.S. have produced what Spener calls "migration-specific habitus," an idea that explains how migrants make sense of their social world, and particularly, the border crossing process and relationship with coyotes as they attempt to evade border security (Spener 2009, 226-229).

Indeed, to comprehend the dangerous landscape migrants navigate, clandestine border crossings must be studied as a wellstructured social process (Singer and Massey 1998). Spener (2009) suggests this dynamic process should include the participation of U.S. Border Patrol agents and coyotes, specifically because as the border is militarized, it is nearly impossible to successfully cross without the assistance of professional smugglers (Cornelius 2005; Donato et al. 2008; Andreas 2009; De León 2012). De León (2012), through his ethnographic and archeological fieldwork, found that a "border crossing industry" has emerged in response to PTD. According to De León, "this industry and its associated goods are constantly evolving as migrants, smugglers, and vendors attempt to adjust to changes in enforcement practices and surveillance technology" (2012, 482). Over the years, the border crossing industry has profited from hopeful migrants, exploited them, and made them more vulnerable throughout this process (Slack and Whiteford 2011; De León 2012).

Today, however, the presence of drug cartels along the Arizona-Sonora border is unprecedented and must be examined as a key factor within this process. In their research, Slack and Whiteford (2011) acknowledge that border militarization has produced a violent overlap in areas where coyotes cross migrants and drug cartels traffic drugs. The militarization of the border, coupled with the drug trade, has given rise to what Spener calls "narco-coyotaje" - the intersection of clandestine migration and drug trafficking $(2009,155)$. While Spener (2009) acknowledges the contemporary phenomenon of narco-coyotaje, he excludes it from his analysis because it was not prevalent in south Texas during his fieldwork. Slack and Whiteford (2011) are among the first scholars to place greater emphasis on as a manifestation on the Arizona-Sonora border. Although scholars have done exemplary work identifying important social actors that influence clandestine migration through the Sonoran Desert, more research is required to explain how migrants engage and interact with narco-coyotaje, how this process differs from previous experiences, and what methods migrants employ to survive. In this regard, ethnographic research in lieu of quantitative studies can be useful in order to unravel the intricacies shadowing today's forms of clandestine migration across the U.S.-Mexico border.

\section{Uncharted Terrains: Fieldwork in a Clandestine Context}

During the summers of 2014 and 2015, I conducted fieldwork at a migrant shelter Albergue Para Inmigrantes San Juan Bosco in Nogales, a Mexican town bordering Nogales, Arizona and located at the headwaters of the 


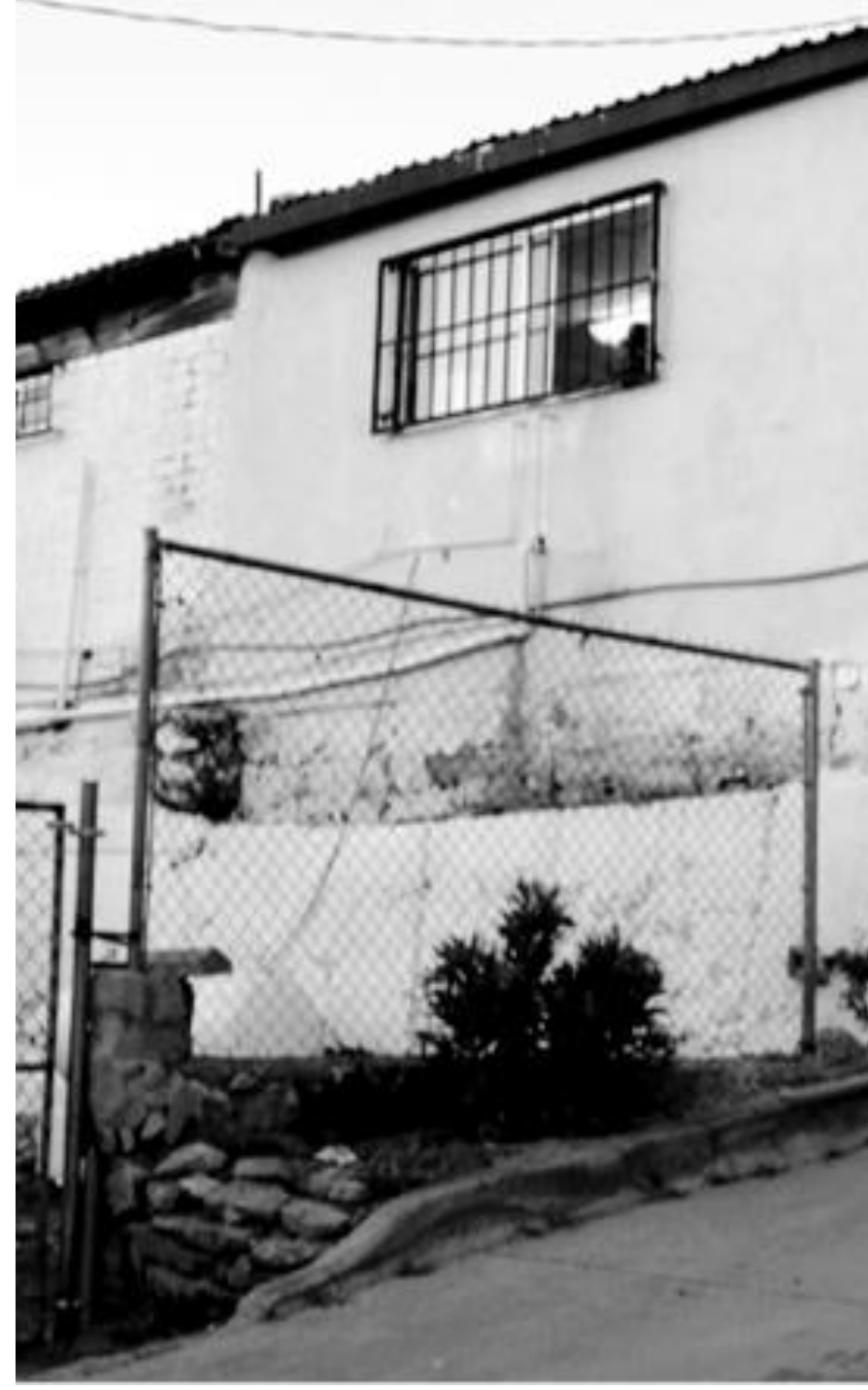

Figure 4: San Juan Bosco migrant shelter. Photo: Bill De La Rosa, 2014.

Sonoran Desert. When Mexican and Central American migrants arrive in Nogales, most have no money, no food, and no place to sleep. For over 30 years, San Juan Bosco has provided temporary sanctuary for individuals deported from the U.S., as well as migrants who would otherwise be exposed to the violence of drug traffickers, bandits, and coyotes. According to the Arizona Daily Star, nearly one million migrants have passed through San Juan Bosco since it first opened (Trevizo 2013). As a research site, this migrant shelter provided a space to interview and engage migrants who were passing through this transitory space and preparing to cross the brutal Sonoran Desert to get to the U.S. (see figure 4).

My ethnographic research included semistructured interviews, participant observation, and informal conversations with migrants who were about to cross the Sonoran Desert or had already been through this experience. Due to the dynamic nature of border crossings, I believe qualitative methods are well-suited for investigating clandestine migration since they enable participants to share-in depth and nuanced experiences. Moreover, by spending time and building rapport with migrants, ethnographic methods allowed me to better capture their everyday lives in a hyper-violent and transitory space. Because I was also a volunteer at the shelter, my position helped me build trust among my participants, allowing them to feel more comfortable sharing their experiences.

My semi-structured interviews focused on the entire migratory process-from the moment individuals left their homes to when they arrived at San Juan Bosco. I asked my participants to explain the reasons they were migrating, their experiences travelling through Mexico, and whether they were planning on crossing the Sonoran Desert, or if they had already crossed it but were apprehended and deported from the U.S. I often heard first-hand accounts of how drug trafficking has become inextricably linked to the human smuggling industry. After a couple of interviews, I used snowball sampling to locate more participants who had encountered drug traffickers in order to further comprehend this evolving process.

Besides semi-structured interviews, I also conducted participant observation and shadowed migrants throughout Nogales, Mexico. At the crack of dawn, migrants are transferred from San Juan Bosco to another shelter where they are provided breakfast, lunch, and medical treatment (Figure 5). From there, a number of them find work while others head to Grupos Beta, a migrant relief center funded by Mexico's National Institute of Migration, until they are finally taken back to San Juan Bosco in the evening to sleep (see figure 6). I began shadowing migrants when two of them, who became great friends with me, invited me to witness this cycle for myself. From sunrise to sunset, I observed on several occasions how migrants lived an everyday life filled with violence and tragedy, yet were simultaneously driven by hope and meaning. 


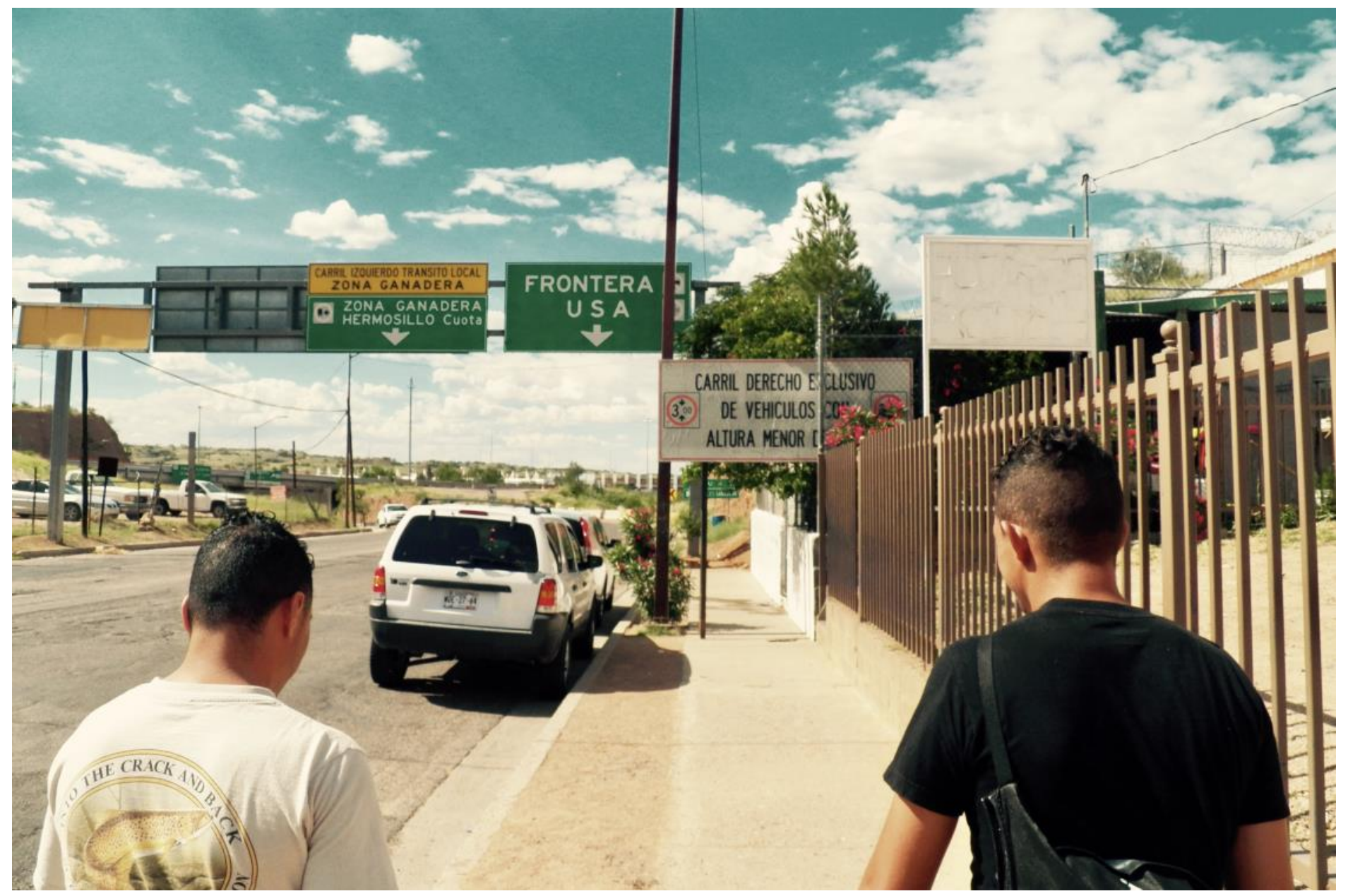

Figure 5: Two migrants on their way to the migrant shelter to eat breakfast in Nogales, Sonora, Mexico. Photo: Bill De La Rosa, 2015.

Throughout my fieldwork, I reflected on my positionality as a researcher within these spaces. I identify as Mexican-American because both of my parents are from Mexico, but I was born in the U.S. However, I lived in Nogales, Mexico, for the first seven years of my childhood, and have continued to return ever since my mother moved back to Nogales in 2009. Because of my familiarity with the area and fluency in Spanish, I believe I built a deeper trust with my participants. That said, I still felt that I embodied what Black feminist scholar Patricia Collins (1986) calls the "outsider within." As a researcher, I often felt like I was deemed an outsider; even though I personally felt a part of the community. On one hand, I could relate to migrant experiences because I had spent several years studying the migratory process in southern Arizona. On the other, I have never attempted to cross the Sonoran Desert and will never know what that experience is like because I am an American citizen. I managed to easily cross the Arizona-Sonora border in my vehicle by showing U.S. Customs and Border Patrol agents my passport while migrants faced death in a brutal desert.

The insights I present in this article are based primarily on sixteen semi-structured interviews, participant observation, and hundreds of conversations that took place over the course of two summers. My interviews ranged in length from 34 minutes to nearly two hours; they were all audio-recorded, transcribed, translated, and password-encrypted to protect people's confidentiality. I assigned all my participants pseudonyms. Although my participant observation consisted of conversations with men and women, all of the interviews were intentionally with men. According to the Migration Policy Institute, nearly $47 \%$ of migrants from Mexico and Central America are women (Ruiz, Zong, and Batalova 2015). While the numbers of men and women migrating to the U.S. are fairly equal, 
their experiences are different, primarily because women are likely to be sexually assaulted. Conscious of this, I purposely only interviewed men because I personally felt unprepared to carry out a conversation with a person who had been a victim of sexual abuse.

Out of the sixteen migrants I interviewed, nine were from Mexico, four from Honduras, two from Guatemala, and one from El Salvador. Furthermore, twelve of them had either been recently deported or deported at some point in their lives and were hoping to return to the U.S. Four of them were planning to cross the Sonoran Desert for the first time. While I did not intend to interview drug mules or human smugglers, a number of my participants happened to have partaken in these processes and trusted me with their stories. Four men were mules for cartels while two had been coyotes and smuggled migrants in the past. Just as Slack and Whiteford (2011) were amazed in their fieldwork, I was also surprised by my participants' honesty, especially because migrant shelters typically do not welcome drug mules or coyotes. Their insights shed light on the evolving process of today's clandestine border crossings and how migrants navigate violent situations.

In the midst of layers of structural violence, migrants are agents drawing on prior migration -specific knowledge, assessing their conditions, and attempting to gain control of their situation. To best illustrate this claim, I first discuss how migrants accumulate social capital during the migratory process; I then explain how migrants are becoming beholden to drug cartels, and finally, I illuminate how clandestine migration unfolds in the Sonoran Desert, where migrants make difficult decisions in order to survive.

\section{Places of Refuge as Spaces of Social Capital}

Decades of migration from Latin America to the U.S. have sustained the production of migration -specific knowledge. For over 30 years, Mexican and Central American migrants have travelled for weeks or months on foot and aboard dangerous freight trains to reach American soil. The social capital that they accumulate from

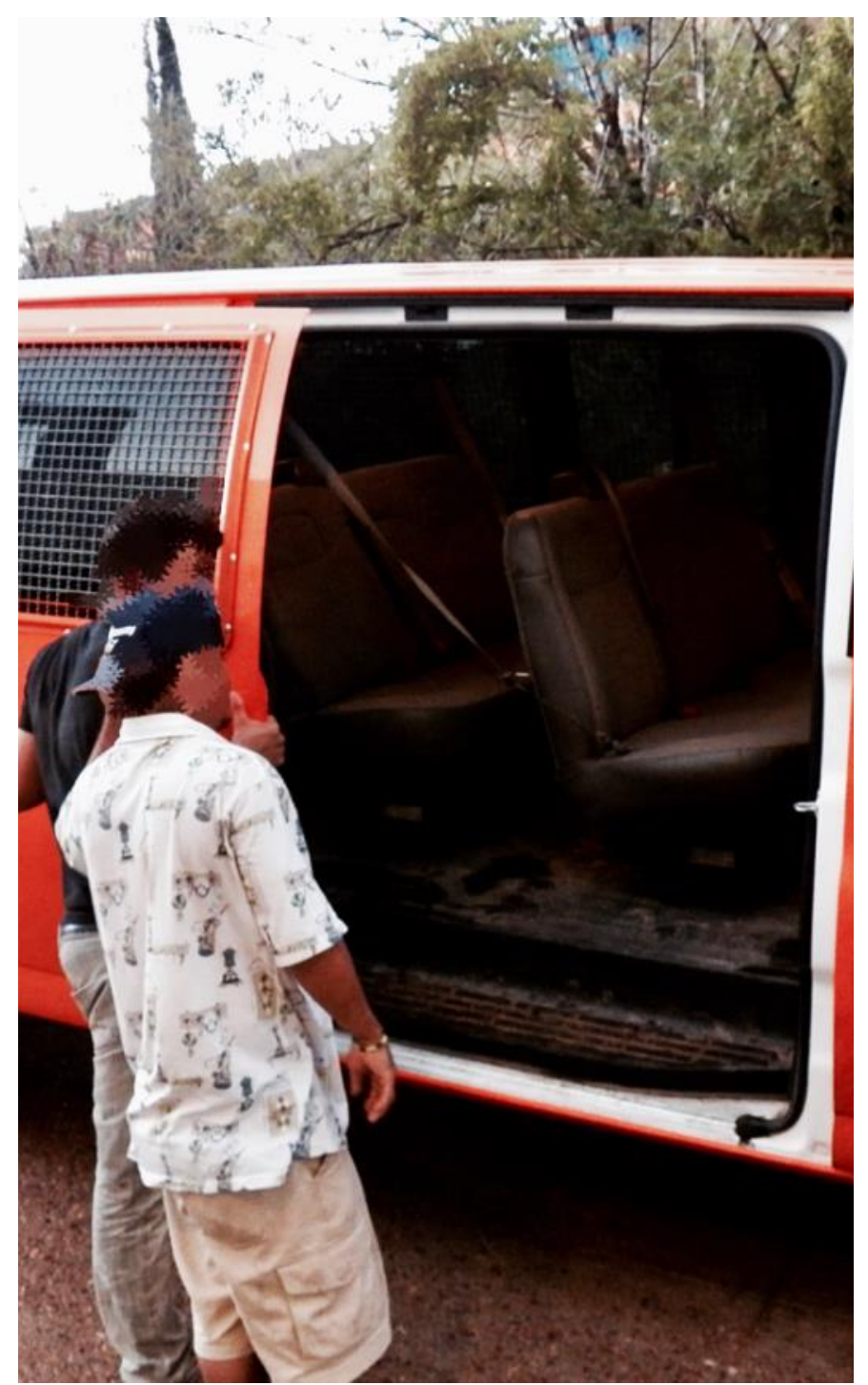

Figure 6: The minibus belonging to Grupos Beta, a Mexican migrant relief organization. Photo: Bill De La Rosa, 2015.

these experiences is then distributed to prospective migrants in their respective communities. As a result, these cyclical patterns of migration have established a well-structured process, one in which migrants learn how to reduce their costs while maximizing their survival through Mexico.

To safely reach the U.S.-Mexico border, humanitarian aid has become a crucial and well -known resource. In response to the perilous migration journey, numerous shelters have emerged throughout Mexico to protect vulnerable migrants from harmful actors. For example, according to Red Derechos Humanos Migrantes, a Mexican nongovernmental organization, there are about 80 shelters in Mexico providing migrants with temporary relief services. Twelve of my research participants whom I interviewed said they relied 
heavily on migrant shelters to make it safely to Nogales. One of them was Melvin, a Guatemalan migrant who stayed at five different shelters prior to arriving at San Juan Bosco:

We ran to Tapachula and then after to Tuxtla Gutiérrez. In Mexico we finished our Q10,000 quetzals, which were about $\$ 20,000$ pesos [ $\$ 1119.7$ dollars]. They were spent on the entire family. We arrived at a migrant shelter in Mexico City. They really helped us, and they also gave me work. After making and saving a little money, we then came to Coahuila, where we stayed with Father Pantoja. He's a good priest who advocates for migrants. He's very well known here in Mexico. We stayed there for two months. The Father and Sister there also helped me find a small job, so I could have an opportunity to earn money. I raised almost $\$ 8,000$ pesos $[\$ 448$ dollars]. Then we came to Ímuris where we met Father Ricardo. He was very nice. We have encountered great people here in Mexico who are trying to save our lives and everything we have. I'm talking to you about six months of travel throughout this course. Father Ricardo then called Father Samuel of the Comedor, and he was told to bring us to Grupos Beta. Afterwards, they brought us over here with all of you at San Juan Bosco.

Melvin migrated with his entire family from Guatemala after gangs murdered two of his sons. Migrant shelters were not only cost-free; they were critical to his family's survival. Although he had no experience migrating, he was aware of humanitarian organizations that offered refuge to families, and as he moved from one place to another, he accumulated knowledge about other shelters. Like him, others also depended heavily on humanitarian efforts during their passage through Mexico.

Humanitarian aid not only protects vulnerable migrants; more importantly, I argue, it plays a profound role in facilitating the production of migration-specific knowledge to successfully cross the U.S.-Mexico border, including the Sonoran Desert. Although unintentionally, San Juan Bosco functioned as a space where migrants had the opportunity to form a network and learn from one another. While there, I consistently observed the distribution of information about clandestine migration and the growing presence of drug cartels.

For instance, migrants shared with each other what objects they should carry to cross the Sonoran Desert. On a warm summer evening, while I spoke with migrants inside the shelter, a Honduran migrant looked down at my tennis shoes and asked if I could sell them to him. Before I could respond, a Guatemalan migrant, who crossed the Sonoran Desert in 2005, immediately answered “That's a bad idea - the desert's heat melts the rubber from tennis shoes, and both rocks and thorns will puncture your feet." He said this while pointing at his rugged boots and encouraging the Honduran migrant to find a pair at a local swap meet. Similarly, other migrants with no border crossing knowledge engaged with others who did have experience. Out of the participants whom I interviewed, four of them attributed the items they purchased in preparation to cross the Sonoran Desert - water, powdered electrolytes, canned food with high-salt content, and dark clothing - to information they gathered in migrant shelters.

The development of social relationships in San Juan Bosco enabled the exchange of social capital, and in this case, migration-specific capital. Besides objects, migrants also counseled each other on techniques for avoiding border security. One evening in June, for example, I sat outside on the front steps of the shelter's entrance and listened to a conversation two men and women were having. One of the men was from Honduras and crossed the Sonoran Desert in 2010. "You have to have a plan," he confidently declared to the others as he made the sign of the cross, "I have a plan and I will use it to get to the U.S. because my children depend on me." He talked about the importance of silence to avoid sound detectors, and thus, apprehension. "People get caught because they're too loud. The Border 
Patrol has special equipment that helps them listen to almost everything." He also recommended avoiding smoking cigarettes at night because a burning ember could be spotted from miles away. Several similar conversations took place on a daily basis. Indeed, San Juan Bosco provided a space for migrants to exchange knowledge and aid one another in their collective struggle to cross the U.S.-Mexico border.

Likewise, humanitarian and governmental organizations that visited San Juan Bosco also circulated important migration-specific knowledge about surviving in the Sonoran Desert. For example, the Mexican Consulate in Nogales, Arizona, and the Human Rights Commission of Sonora stopped by twice a week to inform migrants about their human rights. In addition, they often advised migrants to only engage with human smugglers that they knew personally due to their untrustworthiness and exploitation of people (Spener 2009; Slack and Whiteford 2011). On several occasions, a consular representative suggested that migrants look out for a distinctive, giant peak called Baboquivari, and always keep it on their left, so that they would not become disoriented in the desert. In other instances, he instructed migrants to bring a lighter with them. "Worst comes to the worst," the government official would note as he reached in his pocket for his lighter, "you get your lighter and you light a tree on fire to be rescued."

The same organizations also warned migrants to stay away from the mafia [drug cartels]. They often told horrendous stories to make their point. During my fieldwork, migrants rarely discussed their experiences with drug cartels in public. However, as I interviewed migrants, it became clear how inextricably linked the drug trafficking and human smuggling industries had become. Yet, because this was a relatively new phenomenon, there was no useful knowledge on how to navigate drug cartels. Migrants had to improvise, draw on prior forms of migration-specific knowledge, and make difficult decisions under strenuous circumstances to survive. I discuss this further in the next two sections.

\section{Mules for Cartels}

Today, migrants are becoming drug mules for cartels in exchange for assistance in crossing the Sonoran Desert. First, it is extremely difficult to cross alone and it is expensive to hire a human smuggler. Researchers (Cornelius 2005; Andreas 2009; Spender 2009; De León 2012; De León 2015) have extensively examined how costly crossing the Sonoran Desert has become as border security increases and migrants become reliant on human smugglers. All of my research participants, including those whom I informally spoke to, spent between $\$ 6,000$ and $\$ 9,000$ on a coyote's services. Second, migrants who cross without cartels have to pay extra charges. Slack and Whiteford (2011) have documented the hierarchical relationship between drug cartels, coyotes, and migrants. Since drug cartels claim that coyotes and migrants interfere with their business, migrants must pay a quota, which ranges from $\$ 40$ to $\$ 900$, to drug cartels in order to pass the Arizona-Sonora border. Those who choose to cross the Sonoran Desert without paying their quota risk their lives if caught.

As I stated earlier, four of my research participants were coincidentally mules for cartels, while two of them had worked as coyotes. Their insights offer a glimpse of how violent clandestine border crossings have become. In the following two sections, I focus on the nexus between the drug trafficking and human smuggling industries, or what scholars (Spener 2009, Slack and Whiteford 2011) call "narco-coyotaje." I particularly concentrate on one story to illuminate how migrants become beholden to drug cartels and attempt to draw on migration-specific knowledge in order to gain control and survive in the Sonoran Desert.

Jorge had no idea what he was getting himself into when he went to Sonoyta, a town bordering Lukeville, Arizona. He went there only after he realized there was too much border security in Nogales. Sonoyta is about 120 miles west of Sasabe, and is at the heart of the Sonoran Desert. As we spoke, he took long pauses and deep breaths to remember everything he had experienced in the past two weeks. He wore a forest-patterned camouflage cap, thin hoodie, and sweatpants (see figure 7). 
"When I arrived in Sonoyta, everything became complicated," Jorge said. He went there after he heard he could find a coyote for a modest price; instead, he was deceived and sold to the Sinaloa Cartel. "I saw a woman and I asked her if she could help me find a coyote to cross the desert." The woman agreed to help. "She took me to a man in a safe house, and the man paid her $\$ 20$. The man told me that I had to carry a bag if I wanted to cross into the U.S. He told me he was a coyote, and he offered me food - he went to the store and bought me food, cigarettes, the outfit and these shoes I'm wearing." Jorge said everything in that moment was happening so quickly that he was having trouble processing what he heard, saw, and felt:

Before I could decide whether I wanted to do it, seven armed men arrived at the safe house with eleven more mules, and at that point I realized I couldn't do anything [long pause]. They locked us in that place for a few hours. Then two trucks arrived and they divided us . . . They told us that we were going to smuggle marijuana, get it to Phoenix, and they'd pay us $\$ 1,800$ - but it was false because we made it [takes a deep breath]. A regular coyote charges $\$ 10,000$ pesos $[\$ 560.3$ dollars] to cross people, so that wasn't an option. With $\$ 1,800$, I thought, I can take that amount and send it to my family [long pause]. They took us to the very end of the border about 40 kilometers from Sonoyta, and that's where the drugs were waiting for us. We picked up the drugs and went into the desert immediately.

Jorge had only been in Sonoyta for a few hours before he found himself in the Sonoran Desert with ten kilos of marijuana strapped to his back following two drug cartel guides. He only received four gallons of water, a few cans of tuna, and dried meat. Although most of what Jorge was told turned out false, his thought process at the moment reveals a certain calculus he employed under highly stressful conditions. First, smuggling drugs would not only provide him a ticket to the U.S., it would be cheaper than hiring a coyote. Second, with the money he was promised, he thought about helping his family in Mexico - the people he migrated for in the first place.

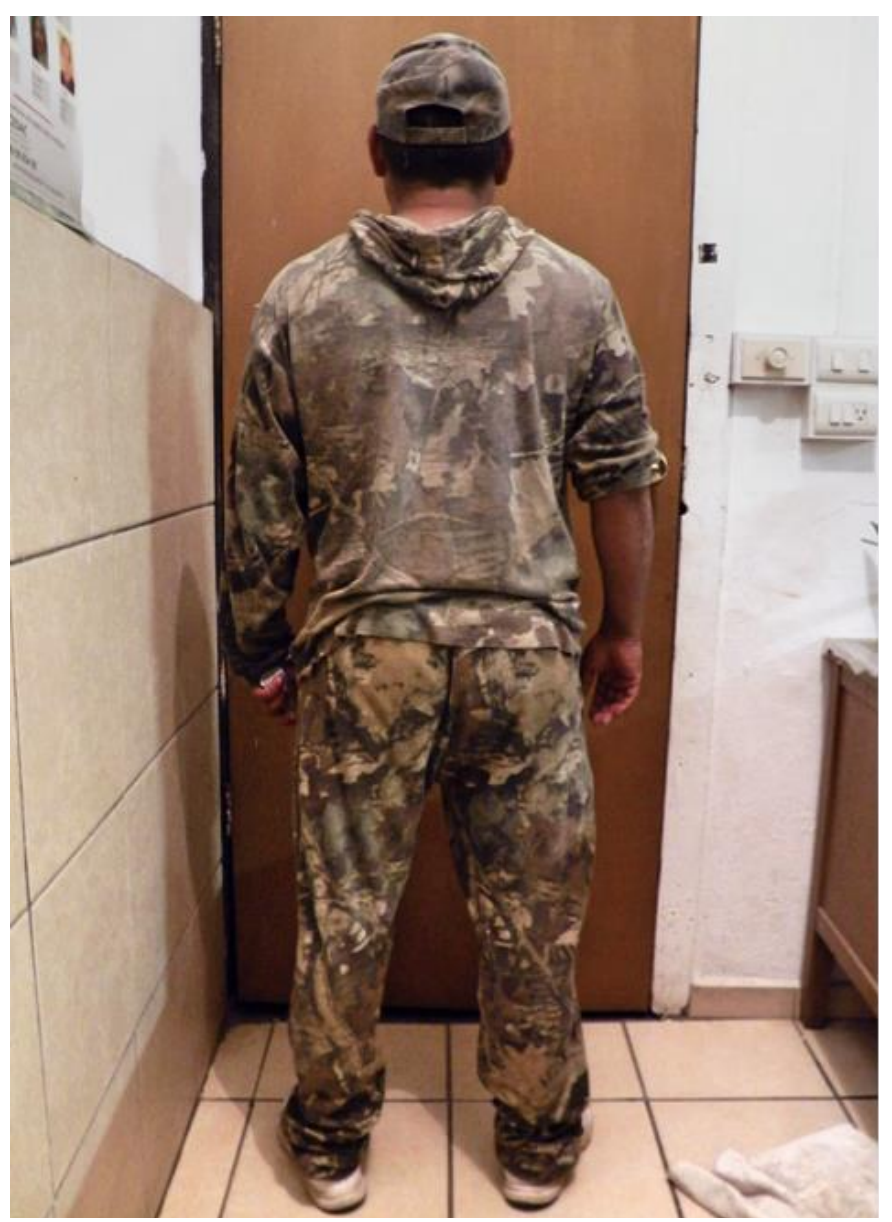

Figure 7: Camouflage clothing. Photo: Bill De La Rosa, 2015.

The experiences of the other three migrants who smuggled drugs were harshly similar. Two of them were abducted and taken to a safe house in Sasabe, a Mexican town bordering Sasabe, Arizona, 30 miles east of Nogales. One of them was given a camouflage outfit, 25 kilos of marijuana, three gallons of water, canned food, and powdered electrolytes. The second migrant said he received "a burlap bag with 20 kilos of marijuana, a camouflaged outfit like the color of the desert [. . .], dried meat, canned food, and powdered milk." Lastly, the third migrant was taken to the outskirts of San Luis Río Colorado, a town bordering San Luis, Arizona. Similarly, he received "20 kilos of marijuana, camouflaged pants and sweater [. . .] a gallon of water and powdered electrolytes," in addition to a pair of carpet-like slippers that are worn over shoes to avoid leaving footprints. 
The violent experiences that my research participants and other migrants encounter before entering the Sonoran Desert represent an aspect of structural violence. They stem from specific structural and political underpinnings, such as widespread poverty in Latin America, U.S. border policy, and American drug demands, which have marginalized migrants and rendered them victims. However, the discourse surrounding structural violence tends to overshadow migrants' individual autonomy, which discredits their resilience and determination to assert control (Slack and Whiteford 2011). I suggest that structural violence resulting from clandestine migration in the Sonoran Desert is highly nuanced. Similar to how migrants prepare to cross the Sonoran Desert, in such a desolate and forbidding space, migrants employ a careful calculus to optimize their survival, especially when drug cartels deliberately reduce their humanity.

\section{Surviving the Sonoran Desert}

Crossing the Sonoran Desert is a dangerous practice. According to the Pima County Office of the Medical Examiner, an average of 163 corpses per year have been found in the Sonoran Desert since 1999 (Martínez et al. 2014). Yet, regardless of how deadly the desert is, thousands of migrants will risk their lives every year due to personal, political, and economic insecurities back home. Numerous scholars (Singer and Massey 1998; Andreas 2009; Spener 2009; De León 2015) have researched successful tactics migrants use to avoid security and survive when crossing the U.S.-Mexico border. However, there is hardly any research examining how migrants experience clandestine migration in the Sonoran Desert while smuggling drugs for cartels.

Immediately after Jorge and the other eleven drug mules began trekking through the Sonoran Desert, he grew increasingly worried. "When I had the bag on," he said, "I felt scared because if they caught me, I was going to get more prison time." In addition to the legal consequences, death weighed on his mind. "What scared me the most," he continued, "was when people began to fall along the journey. There was a 60-year-old man, who became dehydrated, dropped, and died. From twelve, only ten of us made it to the very end." I asked him to recall some of these events. Jorge recounted aloud what happened each day to help him remember:

I felt desperate on the first day. I felt very tense because of the weight. I wasn't ready for it. The next day my load felt heavier. On the third day, I felt worse and that's when it got scarier because that's when the first body dropped. I had to carry ten extra kilos and someone else had to carry ten kilos. The man got a heat stroke and the guides forced us to carry his weight. The guides were in a hurry. They told us, "If he's dead, he's dead. He stays there. Now both of you divide the weight." I saw when he got his stroke. When he collapsed, I hit him on his chest and back. The guides didn't want to stay there. They didn't want to call the paramedics or light a fire. The guides were also armed - so we couldn't do much.

To the drug cartel, migrants were anything but humans. Migrants became mules, working and hauling heavy loads until their bodies could not continue anymore. For migrants, this process was traumatizing. "I felt more scared," Jorge told me when he saw the first man die. "I didn't want to die in a desert and stay there. [The guides] told us, 'whoever can't last, he stays here. What matters to us are the bags and not you."'

Although Jorge was under dire structural constraints, his comments offer a window into how he assessed the moment the 60-year-old man fell to the ground. His first instinct was to help by resuscitating him. Then, although he did not explicitly mention it, he or others proposed to light a fire - a survival technique that most likely was accumulated during the migratory process - to alert the Border Patrol and save the person's life. In the moment, he was not thinking about the legal consequences of getting caught with drugs. And, if it was not for the weapons the drug cartel members carried, the outcome might have been different. However, for Jorge and others, they assessed the situation and concluded that it was in their best interest to follow instructions to live another day. 


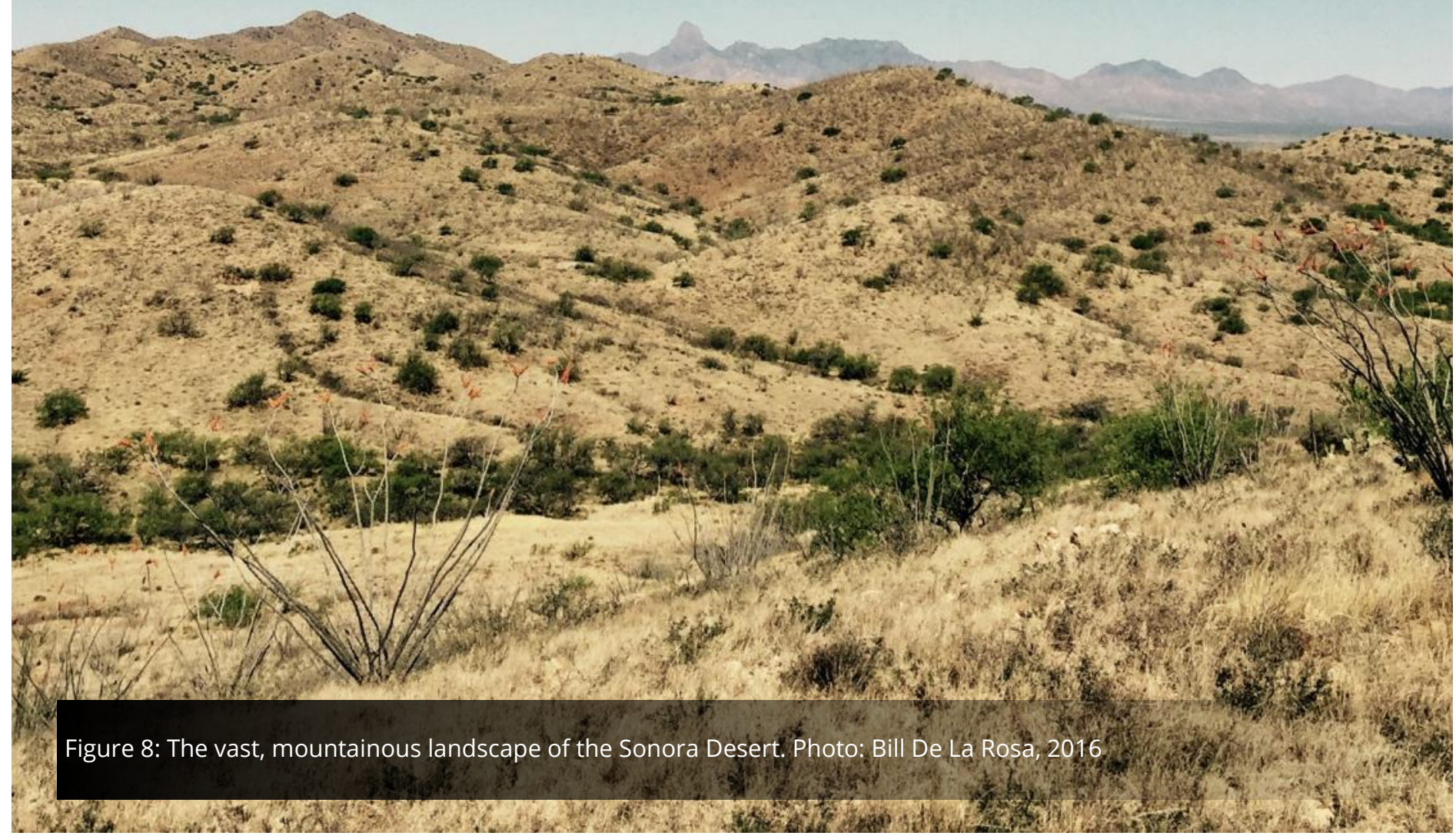


Jorge and the rest of the migrants were out in the Sonoran Desert for eight days total. Figure 8 portrays the vast, mountainous landscape of the Sonoran Desert. In the distance, one can see Baboquivari Peak, which migrants keep to their left in order to avoid disorientation. At the pace that the drug cartel had Jorge and the rest going, the entire journey was anything but a simple hike in the desert. It was a full-on death march. No one talked when they were on the move; everyone faced the ground and watched every step:

We would rest like three or four hours during the night. We walked in the evening, and after 4 p.m., everyone was quiet. We also walked in the night, which made it more dangerous - not the light - it's the fact that you're on the mountains. So some of us would fumble or fall. The guides didn't have any respect for the dignity of anybody. If your bag fell, you picked it up and kept going.

As he told me about how gruesome this process was, I wondered how the drug cartel members were navigating their surroundings. I asked Jorge how they knew where they were headed. He said the drug cartel members had names for specific places in the desert. "There's el cerro de la muela, el cerro del papalote, la brecha del narco, el cerro de la cuna, and el dau." The names translate to the hill of the tooth, the hill of the kite, the gap of the narco, and the hill of the cradle. Both Jorge and I could not discern what the fifth name represented. He became aware of these names because the drug guides kept mentioning them over their radios as they reported their location to the scouts in the mountains. According to Jorge, the drug cartel members also had specific codes. "40," for instance, meant the path was clean, while "60" meant that the Border Patrol was near. These details demonstrate how elaborate the drug trafficking industry has become and depict its dependence on migrants to haul drugs across the desert for its success.

A second man collapsed on the fifth day in the Sonoran Desert. The day before, Jorge remembered observing this particular person not feeling well. "[The man] was heat-ridden," he said. Jorge offered a few electrolyte tablets he had brought along, and a third person helped the man cool down. On the eve of the fifth day, Jorge recalled the young man looked worse. The cartels instructed them to leave him there. However, before they abandoned him, Jorge offered the young man advice:

I told him to start a fire once we left because, if the guides saw him, they would've killed him. When we left, from a distance - we were at a point called el cerro del papalote [the hill of the kite] about 30 kilometers away on top of a mountain - I saw a fire from the direction we came from. A helicopter could be seen in the distance. I saw him start a fire, and the guides were angry. . . they shouted at us. Everyone became tenser; the guides became more agitated.

In this example, Jorge clearly drew from his migration-specific knowledge to save the young man's life. And, telling the young man to light a fire once they were gone, spared his and the others' lives. More importantly, all of this calculation was taking place on the fifth day in the scorching Sonoran Desert under intense desperation and violent circumstances. Moreover, the fact that he can recall the name of the place of where they were offers an added level of precision.

Although the young man was evacuated, there were ten migrants left including Jorge who were fighting to survive. On the seventh day they almost ran out of water. "We had three bags of beans and one of dry meat for all ten of us," he remembered. "The guides were very smart. In one of those water jugs, they'd put both beans and dry meat, and this would make our food last longer. We'd take sips from the jug." Under these conditions, Jorge eventually grew more desperate and confident that he, too, was going to die. I was prompted to ask Jorge whether he ever thought about escaping. He looked up at me, surprised, and said, "I wanted to abandon my group but I didn't want to leave the others behind. There were chavalos [kids] the age of my children in that group. They'd tell me, 'no señor [no sir], don't leave 
us."' While the social structures and the drug cartels systematically reduced his humanity, as one of the oldest migrants, Jorge had grown to feel partly responsible for everyone else. When I heard this, I was taken aback given the strenuous circumstances. Reduced to a mule, throughout this process, Jorge drew strength and a sense of purpose from others.

On the eighth and final day, Jorge and everyone else made it to the drop-off point. It was not Phoenix; it was near Ajo, Arizona, which is about 30 miles from the U.S.-Mexico border. According to Jorge, the final day was the hardest for him:

When we got there, there were men armed with weapons. We turned in the bags, and the deal was that they were going to pay us, and from there, they were going to take us to Phoenix. They wouldn't pay us. They threatened us that they were going to take us to the Border Patrol ... . They threatened us with their weapons. They told us to run to the desert. So, I, along with everyone else, started to run towards the highway. I ran onto the road and waived a truck down. Luckily, it was the Border Patrol. I tried to stop him and he kept going but then he made a U-turn. He didn't turn on his siren. He just made a U-turn, stopped, and got out with a weapon. When I saw this, I got on my knees and put my head down waiting to get shot. He told me I shouldn't be scared because he was the Border Patrol. I said to myself, blessed be God, and cried.

My other three participants who became drug mules shared starkly similar experiences. All of them are just as vivid as Jorge's story. They illuminate the nuances of clandestine migration in the Sonoran Desert, particularly when the presence of drug cartels is factored into the equation. By drawing on prior forms of migration-specific knowledge and carefully assessing their situations, migrants attempt to obtain control of structurally violent conditions. Such perspectives, I hope, contribute to the literature of structural violence, which tends to victimize those who fall outside the margins of power.

\section{Conclusion}

Clandestine migration from Latin America to the U.S. is a pressing issue. President Donald Trump made the politics of immigration the center of his political campaign, and so far, his presidency as well. He relentlessly promises that he will increase U.S. border security to prevent unauthorized border crossings. These claims are not new and have not worked in the past.

Historically, increased border security has had devastating human consequences. One of the principal reasons migrants risk their lives crossing Sonoran Desert is because security strategies that focus on preventing clandestine entries - rather than addressing the multifaceted causes of human migration - have intentionally channeled migration through dangerous corridors. The research is abundantly clear, and the 3,000 plus people that have perished in southern Arizona are testament to the failure of present day U.S. border policy.

More importantly, clandestine migration is a social process. As long as widespread violence, poverty, and desperate spaces of survival exist in Latin America, migrants will continue to adapt to the changes of border security in the search for peace, security, and prosperity, even if it means crossing the Sonoran Desert or acting as mules for cartels.

The purpose of this article was to present a counter-narrative to the common discourse surrounding the literature of structural violence. Such literature has tended to oversimplify people's unique and everyday experiences by ignoring the role of agency. While migrants are indeed victims of vast structural and political inequalities, they are also agents producing meaning, resisting, and fighting for a better tomorrow.

In the context of clandestine migration in the Sonoran Desert, my ethnographic research reveals how migrants are now becoming beholden to drug cartels, and how, in the midst of dire and uncertain circumstances, they 
actively draw on prior forms of migrationspecific knowledge to assert control over their situation. The social capital they accumulate during the migratory process, particularly within migrant shelters, serves as a vital resource for navigating contemporary, hardlyknown clandestine forms of migration. In this respect, migrant shelters are not just humanitarian service providers; they are important actors within clandestine migration frameworks. 


\section{Acknowledgements}

First and foremost, had I not met Dr. Jason De León and joined his Undocumented Migration Project in the summer of 2013, I would have never been inspired to do this research. His work exposed me to the harsh reality of U.S. border policy. More importantly, this article would not have been possible without the support of my mentor and friend, Dr. Marcos López. His guidance has made me the scholar I am today. Additionally, I would also like to thank the following people: Dr. Krista Van Vleet, Dr. Nancy Riley, Dr. Allen Wells, Dr. Janice Jaffe, Dr. Monica Brannon, and Lisa Flanagan. They all provided insightful feedback and challenged my ideas through the course of my research. Second, conducting ethnographic research is a privilege and my experience would have never happened had it not been for the generous funding I received from Bowdoin College and the Mellon Mays Undergraduate Fellowship. Third, I would like to give special acknowledgements to Francisco and Gilda Loureiro, the founders of San Juan Bosco, for the opportunity to conduct fieldwork in their shelter. Fourth, I am thankful for my mother. She is a Mexican immigrant who has also faced the inhumane consequences of U.S. immigration policy. Lastly, to my research participants and the men, women, and children who die trying, this article is dedicated to you. 


\section{References}

Andreas, Peter. 2009. Border Games: Policing the U.S.-Mexico Divide. 2nd ed. Cornell Studies in Political Economy. Ithaca: Cornell University Press.

Bourdieu, Pierre. 1977. Outline of a Theory of Practice. Cambridge Studies in Social and Cultural Anthropology; 16. Cambridge: Cambridge University Press.

Collins, Patricia H. 1986. "Learning from the Outsider Within: The Sociological Significance of Black Feminist Thought." Social Problems 33 (6): S14-32. https://doi.org/10.1525/ sp.1986.33.6.03a00020.

Cornelius, Wayne A. 2001. "Death at the Border: Efficacy and Unintended Consequences of US Immigration Control Policy." Population and Development Review 27 (4): 661-85.

Cornelius, Wayne A. 2005. “Controlling 'Unwanted' Immigration: Lessons from the United States, 1993-2004." Journal of Ethnic and Migration Studies 31 (4): 775-94. https:// doi.org/10.1080/13691830500110017.

De León, Jason. 2012. “'Better to Be Hot than Caught': Excavating the Conflicting Roles of Migrant Material Culture." American Anthropologist 114 (3): 477-495. https://doi.org/10.1111/j.15481433.2012.01447.x.

De León, Jason. 2015. The Land of Open Graves: Living and Dying on the Migrant Trail [Electronic Resource]. California Series in Public Anthropology; 36. Oakland, California: University of California Press. https://ezproxy prd.bodleian.ox.ac.uk/login?url=http:// ebookcentral.proquest.com/lib/oxford/detail.actio? doc $\mid D=2025610$.

Donato, Katherine M., Brandon Wagner, and Evelyn Patterson. 2008. "The Cat and Mouse Game at the Mexico-U.S. Border: Gendered Patterns and Recent Shifts on JSTOR." The International Migration Review 42 (2): 330-59.

Galtung, Johan. 1969. "Violence, Peace, and Peace Research on JSTOR." Journal of Peace Research 6 (3): 167-91. 2018.

"Humane Borders Water Stations." Humane Borders. 2018. https:// www.humaneborders.org/wp-content/uploads/posterpdf/ deathpostercumulative_16_eoy_poster.pdf. 
Inda, Jonathan Xavier. 2006. Targeting Immigrants: Government, Technology, and Ethics. Malden, MA; Oxford: Blackwell Pub.

Jimenez, Maria. 2009. "Humanitarian Crisis: Migrant Deaths at the U.S.-Mexico Border." San Diego: American Civil Liberties Union. https://www.aclu.org/files/pdfs/immigrants/ humanitariancrisisreport.pdf.

Martínez, Daniel E., Robin C. Reineke, Raquel Rubio-Goldsmith, and Bruce O. Parks. 2014. "Structural Violence and Migrant Deaths in Southern Arizona: Data from the Pima County Office of the Medical Examiner, 1990-2013." Journal on Migration and Human Security 2 (4): 257-86. https://doi.org/10.14240/jmhs.v2i4.35.

Nevins, Joseph. 2006. "A Beating Worse Than Death: Imagining and Contesting Violence in the U.S.-Mexico Borderlands." AmeriQuests 2 (1): 1-25. https://doi.org/10.15695/amqst.v2i1.64.

Rubio-Goldsmith, Raquel, Melissa McCormick, Daniel Martinez, and Inez Duarte. 2006. “The 'Funnel Effect' \& Recovered Bodies of Unauthorized Migrants Processed by the Pima County Office of the Medical Examiner, 1990-2005." SSRN Scholarly Paper ID 3040107. Rochester, NY: Social Science Research Network. https://papers.ssrn.com/abstract=3040107.

Ruiz, Ariel G., Jie Zong, and Jeanne Batalova. 2015. “Immigrant Women in the United States." Migrationpolicy.Org. March 19, 2015. https://www.migrationpolicy.org/article/immigrant-womenunited-states.

Singer, Audrey, and Douglas S. Massey. 1998. "The Social Process of Undocumented Border Crossing among Mexican Migrants." International Migration Review 32 (3): 561-92.

Slack, Jeremy, and Scott Whiteford. 2011. "Violence and Migration on the Arizona-Sonora Border." Human Organization 70 (1): 11-21.

Spener, David. 2009. Clandestine Crossings: Migrants and Coyotes on the Texas-Mexico Border. Ithaca: Cornell University Press.

Trevizo, Perla. 2013. "Labor of Love Keeps Immigrant Shelter Open 31 Years." Arizona Daily Star, February 2, 2013. http:// tucson.com/news/local/border/labor-of-love-keeps immigrantshelter-open-years/article_e736f0da-55ee-5d2b-9934d8c0f38374ad.html. 